\title{
ТРАНСФОРМАЦИЯ КОНЦЕПЦИЙ ВЕЛИКОЙ РУССКОЙ РЕВОЛЮЦИИ
}

\section{TRANSFORMATION OF THE CONCEPTS OF THE GREAT RUSSIAN REVOLUTION}

O. Serov

Summary: The centenary of the 1917 revolution in Russia has shown how different the assessments of the Russian revolution are not only in political discourse, but also in historical literature. The October events were called by the participants of these events "the October coup", in Soviet historiography, the seizure of power by the Bolsheviks was called the Great October Socialist Revolution. The concept of the Great Russian Revolution has been established in modern Russian and foreign historical literature.

Keywords: revolution, concept, research.

\author{
Серов Олег Вячеславович \\ К.и.н., доцент, Московский городской \\ педагогический университет \\ gelo.olser@gmail.com
}

Аннотация: Столетний юбилей революции 1917 года в России показал, насколько разнятся оценки русской революции не только в политическом дискурсе, но, и, в исторической литературе. Октябрьские события, назывались участниками этих событий «октябрьским переворотом», в советской историографии, захват власти большевиками назывался Великой Октябрьской Социалистической Революцией. В современной отечественной и зарубежной исторической литературе утвердилась концепция Великой русской революции.

Ключевые слова: революция, концепция, исследования.

исторические центры, где рождается новая историческая наука, и история революции в том числе. В июне 1918 года, по непосредственному указанию Ленина, создаётся Социалистическая академия общественных наук (Соцакадемия), создаются новые периодические издания «Пролетарская революция», «Красный архив» и другие. Необходимо отметить создание специальной Комиссии по изучению истории Октябрьской революции и РКП (б) (Истпарт).

Либеральная трактовка причин русской революции, её оценки, наиболее ярко представлена в книге историка и политического деятеля П.Н. Милюкова «Вторая русская революция». Милюков говорит о необходимости модернизации государственной власти в России, о неспособности царской бюрократии выиграть войну, о политической непригодности самого императора Николая II. Милюков всячески подчёркивает, что ни к каким заговорам он отношения не имел. Большевиков он считал авантюристами, обвинял их в получении денег от Германии, правда, в последние годы его жизни, признавал за большевиками положительную роль в укреплении русской государственности.

Другой представитель либеральной эмигрантской историографии С.П. Мельгунов, собрал материалы, которые придают концепции заговора черты достоверности. Имеется в виду, прежде всего, его книга «На путях к дворцовому перевороту». Сергей Мельгунов отмечает, что как только Россия начала проигрывать «германскую войну» либеральная оппозиция в Государственной думе создаёт Прогрессивный блок. Главной задачей этого бло- 
ка было создание «министерства общественного доверия». Внутри блока, между депутатами Государственной думы, обсуждались списки кандидатов будущего правительства [7: с.171]. Была развёрнута беспрецедентная компания по дискредитации царя, так называемая «распутинщина». Царя обвиняли в назначении министров по указке проходимца Григория Распутина, и, наконец, в желании подписать сепаратный мир с Германией. Так называемая «министерская чехарда», когда происходила лихорадочная замена одних царских министров на других, способствовала укреплению оппозиции и возникновению различных заговоров.

В 1924 году в Советской России выходит сборник «Об «Уроках Октября» где были собраны статьи против Троцкого. Институт красной профессуры выпускает «Очерки по истории Октябрьской революции» под редакцией историка-марксиста М.Н. Покровского, где критикуются идейные позиции Троцкого. Внутрипартийная борьба закончилась поражением Льва Троцкого, его теория перманентной революции была подвергнута проклятиям со стороны советских историков, а Троцкий и его сторонники были объявлены врагами народа. Историк Б.Н. Земцов полагает, что в борьбе с троцкизмом сторонники Сталина приписали В.И. Ленину «теорию социалистической революции» [4: с.19]. Опираясь на работы В.И. Ленина «О лозунге Соединённых Штатов Европы» и «Военная программа пролетарской революции», противники Троцкого доказывали, что Ленин допускал победу социализма в одной стране.

Основополагающий вклад в развитие советской исторической науки внёс историк марксист Михаил Николаевич Покровский. Он закончил историко-филологический факультет Московского университета, готовился стать профессором на кафедре истории, но революция 1905 года сблизила его с большевиками и он пишет исторические труды уже в эмиграции. Победа большевиков в революции 1917 года возносит Покровского на Олимп советской исторической науки. Михаил Покровский становится заместителем А.В. Луначарского, народного комиссара просвещения, занимает руководящие должности в различных организациях, формирующих советскую историческую науку.

М.Н. Покровский организовал Общество историков-марксистов, тесно связанное с Агитпропом ЦК ВКП (б). Общество историков-марксистов издавало журнал «Историк-марксист», который существует до сих пор, под названием «Вопросы истории». Будущие академики Милица Нечкина, Исаак Минц, Анна Панкратова становились комиссарами от истории под руководством Покровского. Кредо Покровского выражает его известная в историографии фраза о том, что история представляет собой политику, опрокинутую в прошлое. В курсе лекций, изданный под названием «Классовая борьба и русская историческая литература» Покровский клеймит буржуазную историографию.

Михаил Покровский стал советским академиком, похоронили его в кремлёвской стене, но и он не избежал репрессий, так сказать посмертно. Иосиф Сталин и его сторонники, победив в борьбе за власть, объявили о возможности построения социализма в одной стране. Споры историков о революции, её предпосылках, характере, стали опасны для сталинского руководства. В 1931 году Сталин пишет письмо в журнал «Пролетарская революция», которое опубликовано под названием «О некоторых вопросах истории большевизма» и указывает советским историкам, что дискуссии по поводу большевизма Ленина недопустимы. Окончательную точку в победе сталинского марксизма-ленинизма поставил знаменитый «Краткий курс», «История ВКП (б). Краткий курс», изданный в 1938 году. Сталинская историография обрушилась на историческое наследие М.Н. Покровского. В постановлении ЦК ВКП (б) и СНК СССР о преподавании истории было объявлено о борьбе с так называемой «школой Покровского». Были изданы сборники статей против «школы Покровского», характерно название статьи Е. Ярославского «Антимарксистские извращения и вульгаризаторство так называемой школы Покровского». Ученица Покровского Анна Панкратова была вынуждена написать статью против своего учителя.

В 1957 году в Академии наук СССР создан научный совет по комплексной проблеме «История Великой Октябрьской Социалистической Революции» под руководством Исаака Минца. Историк, вышедший из Института красной профессуры, из школы Покровского, член Центрального комитета КПСС. Этот совет руководил работой республиканских и региональных секций по всему Советскому Союзу, при нём создаётся комиссия многостороннего сотрудничества академий наук социалистических стран по проблеме «История ВОСР и последующих социалистических революций». Академик Минц публикует свой трёхтомный труд «История Великого Октября», пожалуй, наиболее фундаментальное исследование революции в советской историографии. Трёхтомник был удостоен Ленинской премии, Минц получил Героя социалистического труда, ордена и почётные звания. В 60-е годы формируется «каноническая» советская историография. Происходит масштабная публикация документов по истории партии и революции. Издано свыше 200 томов сборников документов из серии «ВОСР. Документы и материалы» (т. 1-10, М. 1957-1963), видовые публикации: «Декреты Советской власти» (т. 1-2, М. 1957-1959) и другие, тематические публикации: «Экономическое положение России накануне ВОСР» (т.1-3, М. 1957-1967) и другие [2: с.203]. Необходимо отметить, уникальное, по научной проработке, пятое, полное собрание сочине- 
ний В.И. Ленина.

Классовый подход в изучении любых революций ставился во главу угла марксистско-ленинской идеологией. Революции происходят не по прихоти кучки интриганов или «великих личностей», а по воле социальных классов. Какой же социальный класс был движущей силой революции в России? Советские историки, в русле марксистско-ленинской парадигмы, дают однозначный ответ - это пролетариат. Советский историк И.И. Минц пишет: «Революционный подвиг пролетариата, поднявшегося на открытую политическую борьбу вопреки жесточайшим преследованиям, ярко показал, кто является главной движущей силой общественного развития: впервые с начала войны (речь идёт о стачечном движении во время Первой мировой войны. Авт.) на улицу вышла та самая революция, для предотвращения которой предпринималась война» [8: с. 313].

Один из самых авторитетных представителей зарубежной историографии, американский историк Ричард Пайпс, в своей книге «Русская революция» доказывает, что главным виновником революции в России является интеллигенция: «Группы этих «делателей» революции и представляет интеллигенция, которую можно определить как рвущихся к власти интеллектуалов» [10: с. 137]. Интеллигенции, как социальному феномену Пайпс посвятил целую главу. В общем, он отождествляет понятия «интеллигенция» и «интеллектуалы», объясняя появление интеллигенции развитием ремёсел и науки. Русский либерализм, по Пайпсу, мало чем отличается от радикального социализма. Либералы, это та же интеллигенция, бескомпромиссно настроенная против элитарного чиновничества и дворянства. Если в советской историографии революция 1917 года изображается как победа всего прогрессивного человечества, то Ричард Пайпс, однозначно, представляет русскую революцию как величайшую катастрофу, и не только для России, но и для всего мира. В послесловии к своему труду он писал: «Такие традиционные добродетели, как вера в Бога, милосердие, терпимость, патриотизм, трудолюбие, были объявлены новым режимом проклятым наследием обречённого старого мира» [11: с. 538]

Пожалуй, самое существенное различие между подходами И. Минца и Р. Пайпса, это периодизация Русской революции. Книга Минца «История Великого октября» начинается с рассмотрения объективных предпосылок, экономических, политических, для назревания революционного кризиса в России. Отдельно рассматривается роль большевистской партии, причём все остальные партии упоминаются или как социал-шовинисты, или как оппортунисты. Февральская революция 1917 года признаётся результатом борьбы пролетариата, крестьянства и национально-освободительных движений
Российской империи. Кризис верхов проявляется в разложении царской камарильи, страдания и бедствия рабочих и крестьян в тылу, солдат на фронте, делают неизбежным революционный, стихийный взрыв. Однако победой народных масс воспользовалась буржуазия и соглашатели из социалистических партий. Буржуазия организовала Временное правительство, соглашателисоциалисты захватили лидерство в стихийно созданном, по примеру первой революции 1905 года, Совете депутатов в Петрограде. Таким образом, в стране установилось двоевластие. Партия большевиков организует народные массы, во главе с В.И. Лениным, вернувшимся из эмиграции, на борьбу за власть Советов. Буржуазные и мелкобуржуазные партии объединяются против большевиков, Ленин вынужден уйти в подполье, наступает конец двоевластия. Но, политический кризис в стране усугубляется, неспособность Временного правительства управлять страной, особенно резко проявляется в Корниловском мятеже. Народные массы идут за большевиками, происходит большевизация Советов, и, отвечая чаяньям народных масс, большевики берут власть. План вооружённого восстания в Петрограде разработал гениальный Ленин. Решения II Всероссийского съезда Советов ознаменовали победу Великой Октябрьской Социалистической революции. Попытки контрреволюции свергнуть власть большевиков заканчиваются провалом, создаётся первое в мире советское государство, в результате укрепления Советской власти по всей стране, происходит крах буржуазных партий, который выражается в роспуске Учредительного собрания и III Всероссийский съезд Советов провозглашает РСФСР. Итак, в истории России было три революции: 1-я - революция 1905-1907 годов, 2-я - Февральская революция 1917 года и 3-я - Октябрьская революция 1917 года. Великая Октябрьская Социалистическая Революция началась с захвата власти большевиками в октябре 1917 года, и закончилась - III Всероссийским съездом Советов в январе 1918 года.

Ричард Пайпс считает, что не было трёх революций, а была одна Русская революция. Этот подход очень популярен в современной отечественной историографии. Отсюда следует, что Русская революция началась в 1905 году. Пайпс, не оговаривает чётко хронологические рамки революции, но судя по тому, что последняя глава его книги посвящена красному террору и гражданской войне, то, вероятно, концом революции следует считать окончание гражданской войны. Если считать, что гражданская война в России закончилась в 1922 году, то революция в России длилась 17 лет. Единого мнения среди историков на периодизацию гражданской войны и революцию нет. Английский историк Эдвард Карр определяет хронологические рамки «Большевистской революции», то, что у Исаака Минца называется «Октябрьской революцией», с 1917 по 1923 год, то есть, когда вступа- 
ет в силу решение об образовании СССР и конституция CССР [5: с. 11].

Вполне, в духе западной советологии, Пайпс пишет об истоках большевизма, выставляя Ленина кровавым диктатором. Ленин унаследовал самые радикальные черты характерные для революционного движения в России, склонность к террору, ненависть к демократии. Советское государство, благодаря именно Ленину, создавалось как диктатура, то есть было тоталитарным. Октябрьскую революцию Пайпс называет «Октябрьским переворотом», впрочем, сами большевики, включая Ленина, называли её так. Опираясь на эмигрантскую историографию, Пайпс описывает революционные события как череду преступлений. Брест-Литовск или Брестский мир, он трактует как продажу России в пользу Германии. Оправдывает интервенцию стран Антанты, которые защищали свои интересы в России. Описывает военный коммунизм и комбеды в деревне как проявление кровожадности большевиков. Наконец, убийство царской семьи, он целиком возлагает на большевистское правительство и на Ленина. И хотя, у Пайпса, нет ни одной ссылки на исследования эмигрантского историка С.П. Мельгунова по красному террору, выводы Пайпса соотносятся с выводами Мельгунова. Красный террор, по размаху и количеству жертв, превосходит белый террор и несопоставим даже с якобинским террором во времена Французской революции. Для массового уничтожения людей большевики использовали концентрационные лагеря [11: с. 527]. Пайпс видит в Гитлере и Сталине продолжателей дела Ленина.

Несмотря на жёсткий партийный контроль, историческая наука в СССР пыталась развиваться. Наиболее ярко, конфликт между историками-исследователями и партийными чиновниками выразился в разгроме так называемого «нового направления». Историки, в основном сотрудники Института истории СССР Академии наук попытались по новому, с точки зрения сторонников «Краткого курса», взглянуть на социально-экономическое развитие России. В 1973 году вышло постановление ЦК КПСС, где «новое направление» было подвергнуто критике [12: с. 376]. Приверженцев «нового направления» обвиняли в попытке «нового прочтения Ленина», тем самым они допускали отступление от принципиальных положений марксистско-ленинской концепции предпосылок, движущих сил революции в России. Монополистический капитализм в России носил «искусственный характер», империализм объявлялся лишь частью капиталистического уклада, и наиболее крамольная вещь, это отрицание гегемонии пролетариата в российской революции, то, что революция носила народный характер и решала общедемократические задачи. П.В. Волобуев был снят с должности директора Института истории СССР, историку К.Н. Тарновскому, Высшая Аттестацион- ная Комиссия не утвердила докторскую диссертацию.

С приходом к власти М.С. Горбачёва, общественнополитическая ситуация в стране кардинально изменилась, что в свою очередь, вызвало кризис в советской исторической науке. В идеологии Горбачёв объявил «плюрализм», в стране начался «бум» публицистики. То, что до Перестройки называлось антисоветчиной, стало фокусом общественного внимания. В обществе возник небывалый интерес к истории, точнее к интерпретации оценок исторических событий. Многочисленные публицисты принялись искать «правду», которую историки прятали от народа. И сами историки не остались в стороне от жарких споров, в так называемой «профессорской публицистике» скрестили копья ревнители перемен и ортодоксы советской историографии. Профессор Юрий Афанасьев, народный депутат СССР, в своих статьях «Перестройка и историческое знание», «Феномен советской историографии» и других, призывал к переоценке подходов в советской исторической науке. Академик Юрий Поляков в статье «Наше непредсказуемое прошлое» говорил об объективности исторического знания, о необходимости борьбы с политической конъюнктурой.

Трансформация советского мифа о революции 1917 года началась с критики сталинизма. В публицистике началась демонизация Сталина. Все проблемы советской политической системы списывались на сталинизм. Ленин представлялся романтиком революции, открывшим двери человечеству в новый мир социальной справедливости, тогда как Сталин, это злой гений революции. Сталин уничтожил «ленинскую гвардию», свернул НЭП, превратил Советский Союз в тоталитарное государство. Наряду с этим, наблюдалась и обратная тенденция, когда Сталина старались превратить в параноидальную личность или ущербное ничтожество. Характерным примером этого может служить, переведённая в 1989 году на русский язык, книга американского историка Р. Слассера «Сталин в 1917 году. Человек, оставшийся вне революции». Однако, наиболее характерным примером трансформации советского мифа, на наш взгляд, являются работы Д.А. Волкогонова. Наибольший общественный отклик и ожесточенную полемику вызвали его книги из серии «Вожди», написанные в жанре политического портрета, последовательно, о Сталине, Троцком и Ленине. Причём, наибольшую критику, историков и пишущих на исторические темы, вызвали книги о Ленине и Троцком. Ленин был фигурой «неприкасаемой» для идеологического аппарата КПСС, и Дмитрий Волкогонов был частью этого аппарата. Когда КПСС не стало, на Ленина, и без Волкогонова, полились «ушаты грязи». А Волкогонов, оказался «политически конъектурен» для новой российской власти, за серию книг «Вожди» он был награждён государственной премией. Ленин, у Волкогонова, из «непогрешимого борца за счастье человечества», превра- 
тился в хитрого и жестокого политика. Волкогонов «припомнил» Ленину и ошибки в прогнозах на революцию, «реанимировал» претензии эмигрантской историографии к сотрудничеству Ленина и немецкого Генерального штаба, тягу к тирании, диктатуре и наконец, к «кровожадности», приводя цитаты из ленинских записок, где он настаивает на расстрелах.

К западной историографии о Ленине отношение было более спокойным, в стиле «ну что же ждать от антисоветчиков», но Волкогонов, заведовал патриотическим воспитанием в советской армии, получал звания и награды, в его «прозрение», по крайней мере, широкие круги интеллигентской общественности не верили. «Волкогоновский Троцкий» также получил изрядную долю критики. В советской историографии, Троцкий относился к так называемым «фигурам умолчания». Ну, уничтожил Сталин Троцкого, ну, называл Ленин Троцкого «иудушкой», но, чтобы считать Троцкого «большевиком №2», или того хуже, равновеликим Ленину, этого, советская историография, не могла себе представить в самом страшном сне. Волкогонова ругали и за стиль, заголовки из книги о Троцком, «По следам Агасфера», «Бесовство революции», «У кровавой межи», и за тенденциозность подбора источников, хотя и признавали, что многие документы были впервые введены Волкогоновым в научный оборот. Троцкий, у Волкогонова, ничем не уступает в жестокости ни Ленину, ни Сталину. Для революции, Троцкий делает очень нужное дело, привлекает бывших царских офицеров служить в Красную армию, но семьи таких офицеров, приказывает брать в заложники [3: с. 290], он организовывает заградотряды и расстрелы дезертиров [3: с. 286], организовывает «трудовые армии» и первые концлагеря [3: с. 350]. Причину того, что Троцкий проиграл политическую борьбу Сталину, Волкогонов видит в гипертрофированной самоуверенности Троцкого. Троцкий умудрился переругаться со всеми своими соратниками, начиная от Каменева и Зиновьева, и кончая мексиканскими коммунистами. Завершающая характеристика Троцкого у Волкогонова, это «пасынок» эпохи.

Советского Союза не стало, но остались советские историки. В этом смысле, можно говорить не о крахе советской историографии, а о новом, постсоветском периоде, или периоде российской историографии. Важным признаком нового периода было отсутствие контроля рухнувшей КПСС. Исчезла монополия единственно правильной концепции революции. Более того, новая власть не одобряла восхваления революции, марксистско-ленинский подход остался уделом старых советских историков. В историографической полемике, применение марксистско-ленинской методологии оценивается как ретроградство. Появляются заявления о кардинально новых подходах в изучении революции в России: психоментальный, клиометрический, институ- циональный и тому подобное. Б.Н. Миронов, сотрудник Санкт-Петербургского института истории РАН, не без иронии отмечает, что при оценке некоторых концепций затрудняется «оценить гомоэнергетическое истощение этнического ядра империи или степень "симфонизма" священства и царства. Не знаю, как можно доказать или опровергнуть, произошло ли извращение российского мессианизма или что коллизия византийских, монгольских и европейских основ русской истории достигла критического уровня» [9: с. 73].

Ученик академика Волобуева В.П. Булдаков, как раз отказался от марксистско-ленинской методологии и попробовал оценить революцию с психоментальных позиций. В своей монографии «Красная смута. Природа и последствия революционного насилия», в 2010 году вышло дополненное издание, Владимир Булдаков пишет o «хаосе», «охлосе» и тому подобное, опровергая марксистско-ленинскую доктрину о гегемонии пролетариата в социалистической революции. Революция предстаёт как некая вселенская катастрофа, смута, раздирающая страну и прежде всего людей. Необходимо отметить, что взгляд на Русскую революцию как на смуту был представлен ещё в эмигрантской исторической литературе. Например, те же «Очерки русской смуты», воспоминания белогвардейского вождя А.И. Деникина. Вряд ли, стоит соотносить, Русскую революцию XX века, со Смутным временем XVII века.

В главе «Кровь на февральском снегу», В. Булдаков объясняет расправу над морскими офицерами иррациональностью толпы, подстрекательством женщин. Между тем на Черноморском флоте таких эксцессов не было. Неужели харизма адмирала Колчака не позволила появиться иррациональным женщинам в Севастополе. По поводу причин революции, В. Булдаков, естественно, не говорит об империализме, объективных предпосылках революции, но отмечает неизбежность революционных потрясений в России начала XX века, скорее в духе модернизационной теории. В. Булдаков пишет: «В сущности, причина смуты одна - психоз бунта, вызванный бытовой болезненностью ощущений несовершенства власти. Теперь методом жутких проб и ошибок отыскивался идеал, точнее, его видимость. При этом принять желаемое за действительное было тем легче, чем ощутимей были жертвы» [1:с. 284].

Проблематика революции постоянно актуализируется. Казалось бы, «ушедшие в тень» вопросы о тайных пружинах Русской революции, об источниках её финансирования, в последнее время, набирают публицистический накал и уже власть предержащие опасаются, что столетний юбилей Русской революции может спровоцировать ненужное социальное напряжение. В юбилейный год, дискуссия о предпосылках, перешагнула страницы 
научных изданий и продолжает охватывать всё более широкие круги интеллектуалов, пользующихся интернетом. Имеется в виду, полемика, вокруг монографии Б.Н. Миронова «Благосостояние населения и революции в имперской России». Многие историки несогласны с отрицанием кризиса Российской империи накануне 1917 года. С.А. Нефёдов из Уральского института истории и археологии РАН, обвиняет Б.Н. Миронова в ошибках при интерпретации антропометрических данных. В.П. Булдаков, даже, в «аморальности», так как людей низводят до положения скотины, измеряя вес, рост, потребление калорий. Б.Н. Миронов повысил градус полемики, опубликовав свои ответы на критику в книге «Страсти по революции. Нравы в российской историографии в век информации». И это далеко не все дискуссии, которые ведутся по поводу Русской революции. Столетний юбилей революции в России, несмотря на традицию подводить итоги, не означает, что тема закрыта. Классические вопросы для историографии Великой русской революции, причины, движущие силы, итоги, остаются в фокусе обсуждений современных историков.

\section{ЛИТЕРАТУРА}

1. Булдаков В.П. Красная смута. Природа и последствия революционного насилия. М.: РОСПЭН, 1997. 376 с.

2. Великая Октябрьская Социалистическая Революция. Энциклопедия. М. «Советская энциклопедия». 1987. 639 с.

3. Волкогонов Д.А. Троцкий/ Политический портрет. - В двух книгах. - Кн. 1. - М.: Новости, 1992. 416 с.

4. Земцов Б.Н. Историография революции 1917 г. // Международный исторический журнал №2, март-апрель 1999.

5. Карр Эдвард. История Советской России. Книга 1: Том 1 и 2. Большевистская революция, 1917-1923. М.: Прогресс, 1990. 768 с.

6. Ленин В.И. Полн. собр. соч. Т. 45. М.: Госполитиздат, 1958-1965. 718 с.

7. Мельгунов С.П. На путях к дворцовому перевороту. М.: Бородино-Е. 2003, 256 8: с.1: с. с.

8. Минц И.И. История Великого Октября. М.: Наука, 1977. Том 1. 784 с.

9. Миронов Б.Н. Русская революция 1917 года в контексте теорий революции. // Общественные науки и современность. 2013 . №2.

10. Пайпс Ричард. Русская революция. М.: РОСПЭН, 1990. Часть 1. 397 с.

11. Пайпс Ричард. Русская революция. М.: РОСПЭН, 1994. Часть 2.583 с.

12. Поликарпов В.В. «Новое направление» 50-70 годов: последняя дискуссия советских историков. / Советская историография. М.: РГГУ, 1996.590 с.

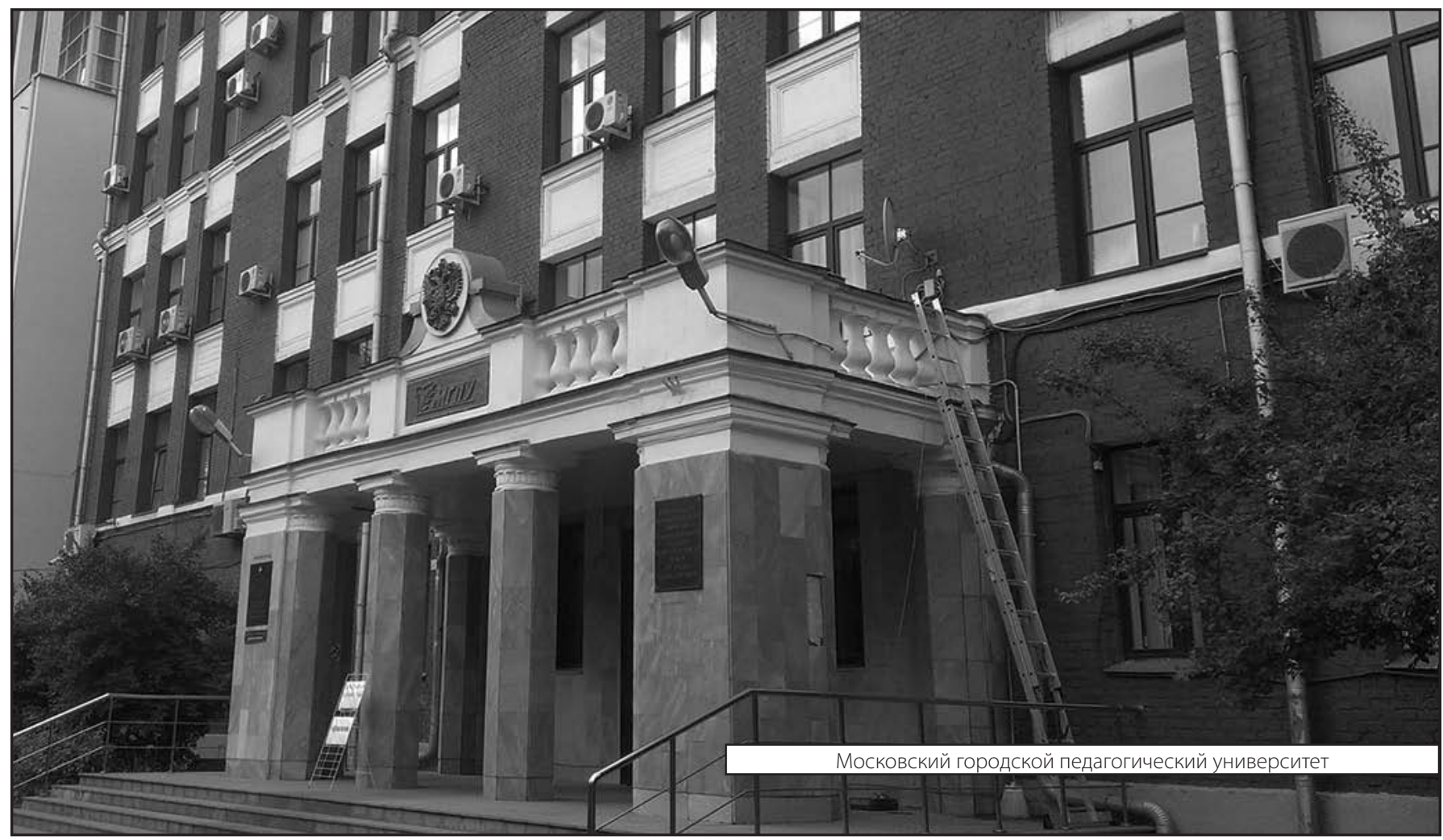

